\title{
A synoptic report on the early winter migrants and resident birds in the coastal wetland of the Marine National Park, Positra, Gujarat
}

\author{
Abhishek Chatterjee ${ }^{1, a}$, Sudeshna Ghosal ${ }^{1, b}$ \\ and Pinakiranjan Chakrabarti ${ }^{*, 1,2, c}$ \\ ${ }^{1}$ Department of Zoology, Vijaygarh Jyotish Ray College, Bejoygarh, Jadavpur, \\ Kolkata- 700032 \\ ${ }^{2}$ Department of Environmental Science, University of Calcutta, 35, Ballygunge Circular Road, \\ Kolkata- 700019 \\ email address: ${ }^{a}$ abc26993@gmail.com, bsudeshnaghosalvjrc@gmail.com, \\ cpinakirc1303@gmail.com \\ *Corresponding author: email address pinakirc1303@gmail.com
}

Keywords: Wetland; Avifaunal diversity; Water-birds; Feeding guilds; Positra; Guajarat.

\begin{abstract}
The study is based on the avian community observed in the region. In total, 524 individuals, 27 genera and 35 species of birds belonging to 21 families have been recorded. Among them, the family Charadriidae with $15.08 \%$ incidence is the most frequent; immediately followed by the family Scolopacidae (11.26\% of occurence). The highest observed species richness has been observed in case of the family Ardeidae. Little Ringed Plover (Charadrius dubius) is the most abundant avian species observed. The community consists of $40 \%$ Resident; $40 \%$ Resident-migrant and $20 \%$ Migrant bird species. It was observed that the concerned community shows a considerable diversity and a corresponding low value of dominance. In the feeding guild analysis, the Insectivore and the Aquatic invertebrate-feeder guilds have the most number of recorded avian species. The feeding guild affiliations also points out that the overall community is fairly rich in its composition as it houses bird species belonging to various feeding guilds.
\end{abstract}

\section{INTRODUCTION}

According to the Article 1.1 of the Convention on Wetlands (Ramsar, Iran, 1971); it is stated that "For the purpose of this Convention wetlands are areas of marsh, fen, peat-land or water, whether natural or artificial, permanent or temporary, with water that is static or flowing, fresh, brackish or salt, including areas of marine water the depth of which at low tide does not exceed six metres.". Wetlands are among the most productive ecosystems in the world and play vital role in flood control, aquifer recharge, nutrient absorption and erosion control. . In addition, wetlands provide home for a huge diversity of wildlife such as birds, mammals, fish, frogs, insects and plants [1]. Thus wetlands help in maintaining biodiversity of flora and fauna. Wetland supports congregation of large number of migratory and resident species of birds as it has high nutritional value as well as productivity [2, 3, 4]. As per Ali and Ripley (1983), 273 species of birds in India can be considered as waterfowls, the birds that depend on wetland ecosystem [5]. These birds use wetland habitats either throughout or during certain part of their life [6].

Birds are ideal bio-indicators and useful models for studying a variety of environmental problems [7]. Birds occupy a wide range of ecological positions [8]. In many respects biodiversity, both present and past is better understood for birds than for any other major group of organisms. One basic approach in generating an indicator of the state of wildlife is to measure diversity through time. Species loss or gain could then be used to gauge the trends in biodiversity [9]. Thus the avifaunal diversity of a region is a very prompt indicator of the environmental conditions of the concerned place.

The Marine National Park is quite a popular tourist destination and most of that activity is concentrated towards the Jamnagar side and Pirotan Island (one of the 42 islands on the Jamnagar coast in the Marine National Park). Situated in the intertidal zone, between the lowest and highest 
tide levels, the park supports a variety of habitats such as coral reefs, mudflats, creeks, mangroves, estuaries, sandy strands to saline grasslands, marshy areas and rocky shores. Coral reefs are the prime tourist attraction of the park. This national park is among the few in the world where one can observe coral reefs and the associated fauna without having to take a dive underwater. As many 52 different coral reefs can be found at the park, of which 42 are hard and 10 soft. Some of the finest coral reefs can be found at Pirotan, Narara, Ajad and Positra. The park supports as many as 108 species of algae, 56 types of corals, 70 species of sponges, 200 of fish, 27 types of prawns, 30 of crabs, over 400 species of molluscs, 175 species of birds and three species of turtles, mammals and sea snakes. [10]

Hence, naturally, most activities are concentrated around marine life in this national park. There are not many scientific works regarding the avifauna of the place. Our work is aimed at filling in that gap. Hence, this study is of unique importance, focusing mainly on the wide spectrum of birds that are available there and on their feeding habits; which in turn reveal the composition of a greater part of the ecological community present in the region.

\section{MATERIALS AND METHODS}

\subsection{Study area}

Gujarat is located on the Tropic of Cancer (Lat $20^{\circ} 01^{\prime}$ to $24^{\circ} 07^{\prime} \mathrm{N}$ and Long $68^{\circ} 04^{\prime}$ to $74^{\circ} 04^{\prime} \mathrm{E}$ ); falls in the sub-tropical climatic zone and has a varied climate and climatic regions [11]. Kachchh, ( $22^{\circ} 41^{\prime} 11^{\prime \prime}$ to $24^{\circ} 41^{\prime} 47^{\prime \prime} \mathrm{N}$ and $68^{\circ} 9^{\prime} 46^{\prime \prime}$ to $\left.71^{\circ} 54^{\prime} 47^{\prime \prime}\right)$, extending over $45,652 \mathrm{sq}$. $\mathrm{km}$. area lies in the western part of Gujarat state and falls under the Desert bio-geographic zone and 3B DesertKachchh Province [12].There are many natural seasonal wetlands in Kachchh. In total about 258 wetlands were delineated through satellite imageries. These wetlands cover approximately $21772 \mathrm{~km}^{2}$ area, which is more than $80 \%$ of the entire state [13].
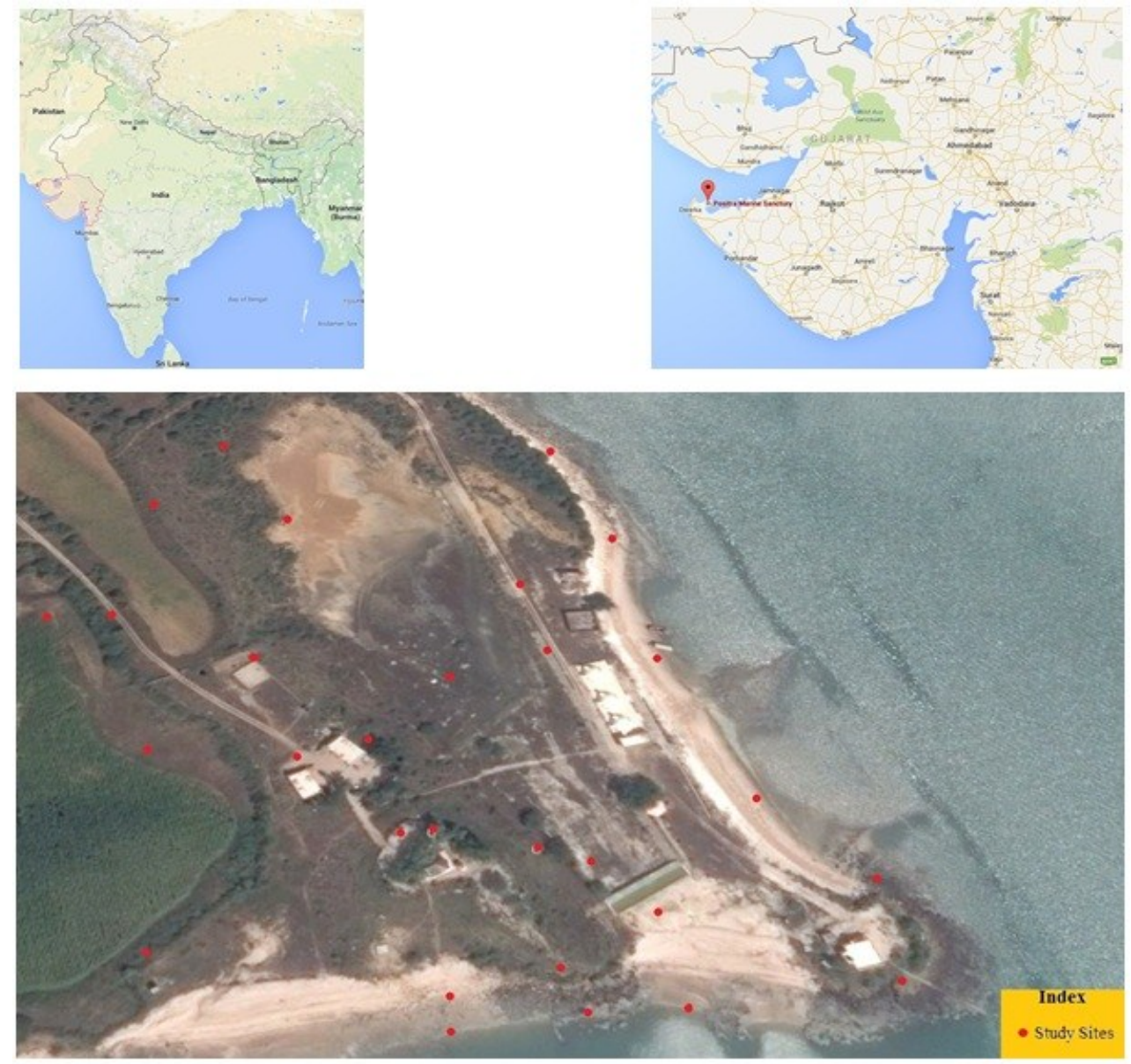

Figure 1: Satellite image of Positra Marine Sanctuary and its adjacent regions with the study-sites marked as red dots 
The study was carried out in the vicinity of the Positra Marine Sanctuary, Positra, Gujarat (at the intersection of $22^{\circ} 23^{\prime} 20^{\prime \prime} \mathrm{N}$ latitude and $69^{\circ} 11^{\prime} 49^{\prime \prime} \mathrm{E}$ longitude). The sanctuary is located at a distance of $11.4 \mathrm{~km}$ due east from the nearest landmark city of Positra. We have considered this coastland as a marine wetland ecosystem, since, during low tide the water level of the sea (as seen in Figure 1) recedes a great distance of 200 to 250 meters and even after that up to another 500 meters the water level does not exceed a depth of 6 meters. Hence, according to the RAMSAR conventions (as mentioned in the introduction), this coastland system is actually a wetland ecosystem. The sites for study on the seashore and surrounding regions are marked in the satellite image of the sanctuary given in Figure 1.

\subsection{Bird species survey}

The survey was conducted in early and late-December of 2013. Mostly two kinds of transect methods were used for gathering the information on bird species abundances and identities; namely, the Line Transect and the Point Transect methods [14]. During the surveys, birds were identified early in the morning from 06:00 to 10:00 hours and late afternoon from 16:00 to 18:30 hours when the temperature was relatively cool (in the morning, the temperature usually remains within 31$33^{\circ} \mathrm{C}$ and in the evening it is usually within $27-29^{\circ} \mathrm{C}$ ). Birds were identified with the aid of standard field guide [15]. On every occasion, the counting distance was restricted to around $50 \mathrm{~m}$ for identification purposes. Birds that flew overhead but did not land in the sites were also recorded. The checklist was prepared following the standardized common and scientific names of the birds of the Indian subcontinent by Manakkadan and Pittie (2001) [16].

\subsection{Statistical analyses}

The various richness (species, genus and family) indices, Shannon evenness (J'), Shannon-Wiener diversity (H'), Simpson's Diversity Index (l) and Simpson's index of dominance (D') have been calculated [17]. The various indices were computed using the software, PAST (version 3.08) [18]. From the value of the Shannon-Wiener diversity index, the Effective Number of Species (ENS), a way of converting diversity measures to an easily interpretable linear scale, has been derived [19]. Shannon's diversity index is converted by taking its exponential; ENS=exp $\left(H^{\prime}\right)$, where, $H^{\prime}$ is the value of the Shannon-Wiener diversity index [19]. Evenness ranges from 0 to 1 and as it approaches 1 , individuals are partitioned equally among species. High values of $\mathrm{H}^{\prime}$ and low values of $\mathrm{D}^{\prime}$ indicate high species diversity [17].

\section{RESULT AND CONCLUSION}

The overall scenario of the avifaunal community observed at the study-site is provided in Table 1 . Overall, 542 individuals of thirty-five (35) different species of birds, belonging to twenty-seven (27) different genera and twenty-one (21) families; have been recorded during the study period. The observed birds belong to only two IUCN Categories, viz. Least Concerned (LC) and Near Threatened (NT) [20]. Among the observed 35 avian species, twenty-nine of them (82.85 percent), belong to the Least Concerned category; whereas, only six bird species (17.14 percent), viz. the Jouanin's Petrel (Bulweria fallax), Darter (Anhinga melanogaster), Painted Stork (Mycteria leucocephala), Oriental White Ibis (Threskiornis melanocephalus), Eurasian Curlew (Numenius arquata) and Bar-tailed Godwit (Limosa lapponica) belong to the Near Threatened category. 
Table 1: Checklist of the diverse array of bird species observed at Positra

\begin{tabular}{|c|c|c|c|c|c|c|}
\hline $\begin{array}{l}\text { Serial } \\
\text { No. }\end{array}$ & Bird Name & Family & Scientific Name & $\begin{array}{l}\text { Mig- } \\
\text { ration } \\
\text { Status }\end{array}$ & $\begin{array}{l}\text { Feeding } \\
\text { habit }\end{array}$ & $\begin{array}{c}\text { IUCN } \\
\text { Categ- } \\
\text { ory }\end{array}$ \\
\hline 1. & Jouanin's Petrel & Procellariidae & Bulweria fallax & $\mathrm{R}$ & $\mathrm{P}, \mathrm{IN}$ & NT \\
\hline 2. & Great White Pelican & Pelicanidae & $\begin{array}{c}\text { Pelecanus } \\
\text { onocrotalus }\end{array}$ & RM & $\mathrm{P}$ & $\mathrm{LC}$ \\
\hline 3. & Little Cormorant & $\begin{array}{c}\text { Phalacrocoraci- } \\
\text { dae }\end{array}$ & $\begin{array}{c}\text { Phalacrocorax } \\
\text { niger }\end{array}$ & RM & $\mathrm{P}$ & $\mathrm{LC}$ \\
\hline 4. & Darter & Anhingidae & $\begin{array}{c}\text { Anhinga } \\
\text { melanogaster }\end{array}$ & $\mathrm{RM}$ & $\mathrm{P}$ & NT \\
\hline 5. & Grey Heron & Ardeidae & Ardea cinerea & $\mathrm{R}$ & $\mathrm{P}, \mathrm{A}$ & $\mathrm{LC}$ \\
\hline 6. & Purple Heron & Ardeidae & Ardea purpurea & RM & $\mathrm{P}, \mathrm{A}, \mathrm{OP}$ & $\mathrm{LC}$ \\
\hline 7. & Large Egret & Ardeidae & Ardea alba & $\mathrm{R}$ & $\mathrm{P}, \mathrm{A}$ & $\mathrm{LC}$ \\
\hline 8. & Little Egret & Ardeidae & Egretta garzetta & RM & $\mathrm{P}, \mathrm{RP}, \mathrm{IN}$ & $\mathrm{LC}$ \\
\hline 9. & Western Reef Egret & Ardeidae & Egretta gularis & RM & $\mathrm{P}, \mathrm{IN}$ & $\mathrm{LC}$ \\
\hline 10. & Painted Stork & Ciconidae & $\begin{array}{c}\text { Mycteria } \\
\text { leucocephala }\end{array}$ & $\mathrm{RM}$ & $\mathrm{P}, \mathrm{IN}$ & NT \\
\hline 11. & Oriental White Ibis & $\begin{array}{l}\text { Threskiornithi- } \\
\text { dae }\end{array}$ & $\begin{array}{c}\text { Threskiornis } \\
\text { melanocephalus }\end{array}$ & $\mathrm{R}$ & A, IN, I & NT \\
\hline 12. & Brahminy Kite & Accipitridae & Haliastur indus & $\mathrm{R}$ & $\begin{array}{l}\text { IN, P, RP, } \\
\text { C, PD }\end{array}$ & $\mathrm{LC}$ \\
\hline 13. & $\begin{array}{l}\text { White-bellied Sea } \\
\text { Eagle }\end{array}$ & Accipitridae & $\begin{array}{l}\text { Haliaeetus } \\
\text { leucogaster }\end{array}$ & $\mathrm{R}$ & $\mathrm{P}, \mathrm{RP}, \mathrm{PD}$ & $\mathrm{LC}$ \\
\hline 14. & Indian Peafowl & Rallidae & Pavo cristatus & $\mathrm{R}$ & $\mathrm{G}, \mathrm{OP}$ & LC \\
\hline 15. & Lesser Sand Plover & Charadriidae & $\begin{array}{c}\text { Charadrius } \\
\text { mongolus }\end{array}$ & $\mathrm{RM}$ & $\mathrm{I}, \mathrm{IN}$ & $\mathrm{LC}$ \\
\hline 16. & Grey Plover & Charadriidae & $\begin{array}{c}\text { Pluvialis } \\
\text { squatarola }\end{array}$ & $\mathrm{M}$ & IN & $\mathrm{LC}$ \\
\hline 17. & Little Ringed Plover & Charadriidae & Charadrius dubius & RM & $\mathrm{I}, \mathrm{IN}$ & LC \\
\hline 18. & Green Sandpiper & Scolopacidae & Tringa ochropus & $\mathrm{M}$ & $\mathrm{P}, \mathrm{I}, \mathrm{IN}$ & $\mathrm{LC}$ \\
\hline 19. & Common Redshank & Scolopacidae & Tringa totanus & RM & $\mathrm{P}, \mathrm{IN}, \mathrm{I}$ & $\mathrm{LC}$ \\
\hline 20. & Common Greenshank & Scolopacidae & Tringa nebularia & $\mathrm{M}$ & $\mathrm{P}, \mathrm{I}, \mathrm{IN}$ & $\mathrm{LC}$ \\
\hline 21. & Ruddy Turnstone & Scolopacidae & Arenaria interpres & $\mathrm{M}$ & $\mathrm{P}, \mathrm{I}, \mathrm{IN}, \mathrm{C}$ & $\mathrm{LC}$ \\
\hline 22. & Black-winged Stilt & Recurvirostridae & $\begin{array}{l}\text { Himantopus } \\
\text { himantopus }\end{array}$ & $\mathrm{R}$ & IN & $\mathrm{LC}$ \\
\hline 23. & Eurasian Curlew & Recurvirostridae & Numenius arquata & $\mathrm{M}$ & I, RP & NT \\
\hline 24. & Bar-tailed Godwit & Recurvirostridae & Limosa lapponica & $\mathrm{M}$ & $\mathrm{I}, \mathrm{IN}, \mathrm{FU}$ & NT \\
\hline 25. & Black-headed Gull & Laridae & Larus ridibundus & $\mathrm{M}$ & $\mathrm{I}, \mathrm{IN}, \mathrm{G}$ & $\mathrm{LC}$ \\
\hline 26. & Whiskered Tern & Sternidae & Chlidonias hybrid & RM & I, IN & $\mathrm{LC}$ \\
\hline 27. & Little Tern & Sternidae & Sterna albifrons & $\mathrm{R}$ & $\mathrm{P}, \mathrm{I}, \mathrm{IN}$ & $\mathrm{LC}$ \\
\hline 28. & Oriental Turtle Dove & Columbidae & $\begin{array}{c}\text { Streptopelia } \\
\text { orientalis }\end{array}$ & $\mathrm{RM}$ & G & $\mathrm{LC}$ \\
\hline 29. & Little Swift & Apodidae & Apus affinis & RM & $\mathrm{I}$ & $\mathrm{LC}$ \\
\hline 30. & Yellow Wagtail & Motacillidae & Motacilla flava & RM & $\mathrm{I}$ & LC \\
\hline 31. & Large Pied Wagtail & Motacillidae & $\begin{array}{c}\text { Motacilla } \\
\text { maderaspatensis }\end{array}$ & $\mathrm{R}$ & I & $\mathrm{LC}$ \\
\hline 32. & White -eared Bulbul & Pycnonotidae & $\begin{array}{c}\text { Pycnonotus } \\
\text { leucotis }\end{array}$ & $\mathrm{R}$ & FU,I & $\mathrm{LC}$ \\
\hline 33. & Indian Robin & Muscicapidae & $\begin{array}{c}\text { Saxicoloides } \\
\text { fulicatus }\end{array}$ & $\mathrm{R}$ & I & $\mathrm{LC}$ \\
\hline 34. & Common Babbler & Timalidae & Turdoides caudata & $\mathrm{R}$ & $\mathrm{I}, \mathrm{FU}, \mathrm{G}$ & LC \\
\hline 35. & Oriental White Eye & Dicaeidae & $\begin{array}{c}\text { Zosterops } \\
\text { palpebrosus }\end{array}$ & $\mathrm{R}$ & $\mathrm{I}, \mathrm{FU}$ & $\mathrm{LC}$ \\
\hline
\end{tabular}


In the study, twenty-one (21) families of birds have been observed; among which the family Ardeidae has recorded the highest observed number of species (as shown in Table 2) in the avian community. The family Charadriidae with $15.08 \%$ incidence is the most frequent one to be observed and quite naturally the most abundant species, i.e. the Little Ringed Plover (Charadrius dubius) also belongs to the said family.

Table 2: Distribution of various birds observed is arranged according to their respective families with the respective number of genus and species of avifauna observed to belong under them.

\begin{tabular}{|c|c|c|c|c|}
\hline $\begin{array}{l}\text { Sr. } \\
\text { No. }\end{array}$ & Name of the Family & $\begin{array}{c}\text { No. of Genus } \\
\text { observed }\end{array}$ & $\begin{array}{c}\text { No. of Species } \\
\text { observed }\end{array}$ & $\begin{array}{l}\text { Percentage } \\
\text { of } \\
\text { occurrence }\end{array}$ \\
\hline 1. & Procellariidae & 1 & 1 & 0.38 \\
\hline 2. & Pelicanidae & 1 & 1 & 3.82 \\
\hline 3. & Phalacrocoracidae & 1 & 1 & 2.29 \\
\hline 4. & Anhingidae & 1 & 1 & 1.15 \\
\hline 5. & Ardeidae & 2 & 5 & 8.21 \\
\hline 6. & Ciconidae & 1 & 1 & 7.25 \\
\hline 7. & Threskiornithidae & 1 & 1 & 2.10 \\
\hline 8. & Accipitridae & 2 & 2 & 2.10 \\
\hline 9. & Rallidae & 1 & 1 & 2.86 \\
\hline 10. & Charadriidae & 2 & 3 & 15.08 \\
\hline 11. & Scolopacidae & 2 & 4 & 11.26 \\
\hline 12. & Recurvirostridae & 3 & 3 & 10.69 \\
\hline 13. & Laridae & 1 & 1 & 7.63 \\
\hline 14. & Sternidae & 2 & 2 & 5.34 \\
\hline 15. & Columbidae & 1 & 1 & 2.48 \\
\hline 16. & Apodidae & 1 & 1 & 5.34 \\
\hline 17. & Motacillidae & 1 & 2 & 2.10 \\
\hline 18. & Pycnonotidae & 1 & 1 & 3.24 \\
\hline 19. & Muscicapidae & 1 & 1 & 0.95 \\
\hline 20. & Timalidae & 1 & 1 & 5.34 \\
\hline 21. & Dicaeidae & 1 & 1 & 0.38 \\
\hline
\end{tabular}

All the different kinds of migration categories, viz. the Resident (R) Birds, the Resident-Migrant (RM) Birds and the Migrant or Migratory (M) Birds have been observed during the survey. There has been observed 14 Resident (40 percent), 14 Resident-Migrant (40 percent) and 7 Migratory (20 percent) bird species. Therefore, in total, 21 migratory bird species have been recorded [Figure 2]; which account for 60 percent of the observed avian community. 


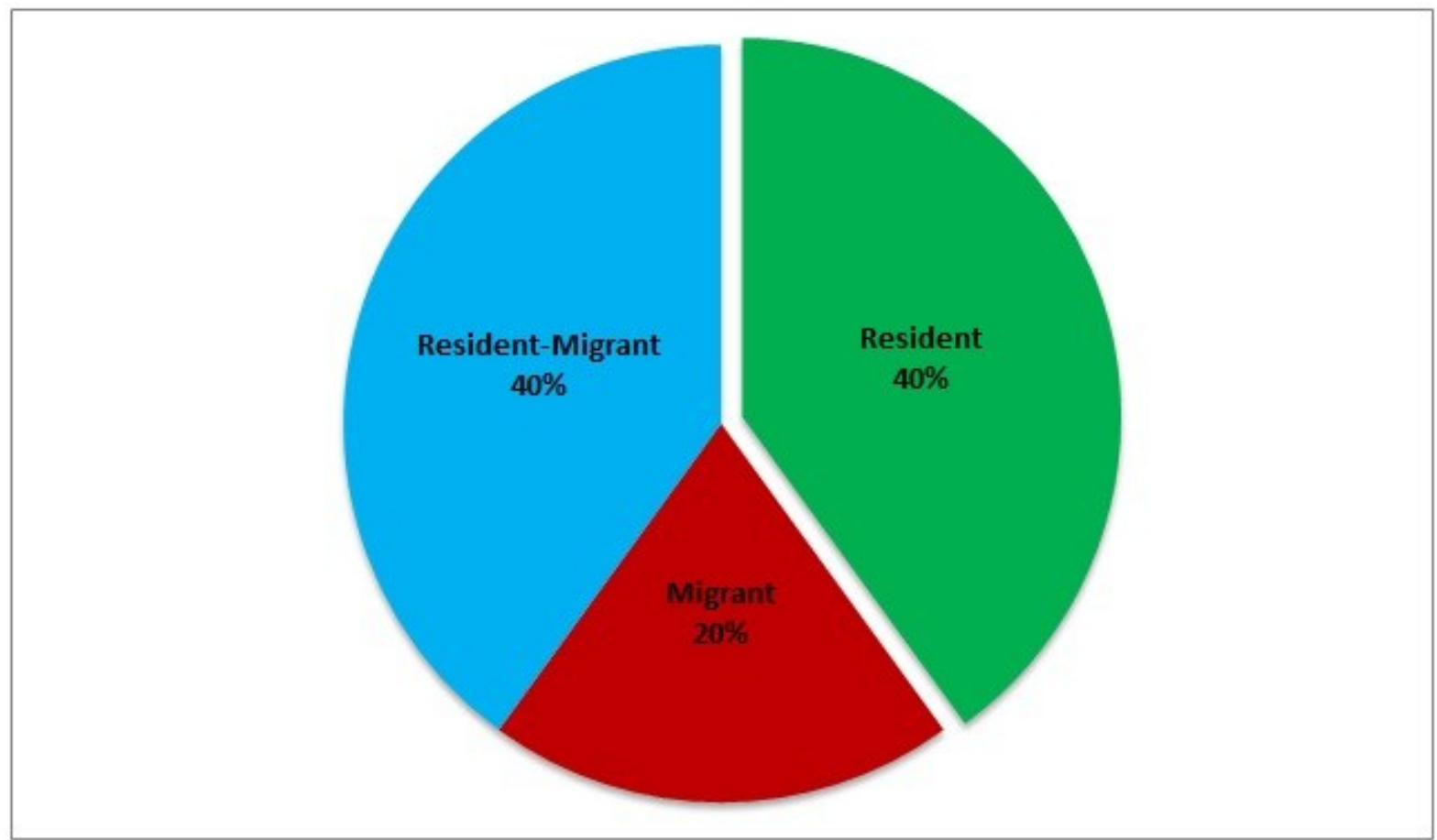

Figure 2: Exploded pie chart showing the number of bird species observed according to their Migration Categories

There have also been identified ten (10) kinds of Feeding Guilds, viz. Aquatic invertebrate-feeder $(I N)$, Piscivore $(P)$, Insect and other terrestrial invertebrate feeder $(I)$, Grainivore $(G)$, Frugivore $(F U)$, Reptile-feeder $(R)$, Ophidiovore $(O P)$, Amphibian-feeder $(A)$, Carrion-feeder $(C)$ and Predatory $(P D)$; among the bird species observed [21] (Figure 3). Here, the Insectivore (I) and the Aquatic invertebrate-feeder (IN) guilds are the most frequent one with twenty-four percent incidence and 18 observed avian species occurs under these shared categories. Whereas Ophidiovore (OP), Carrion-feeder (C) and Predatory (PD) guilds are the least frequent with only two species observed in each case.

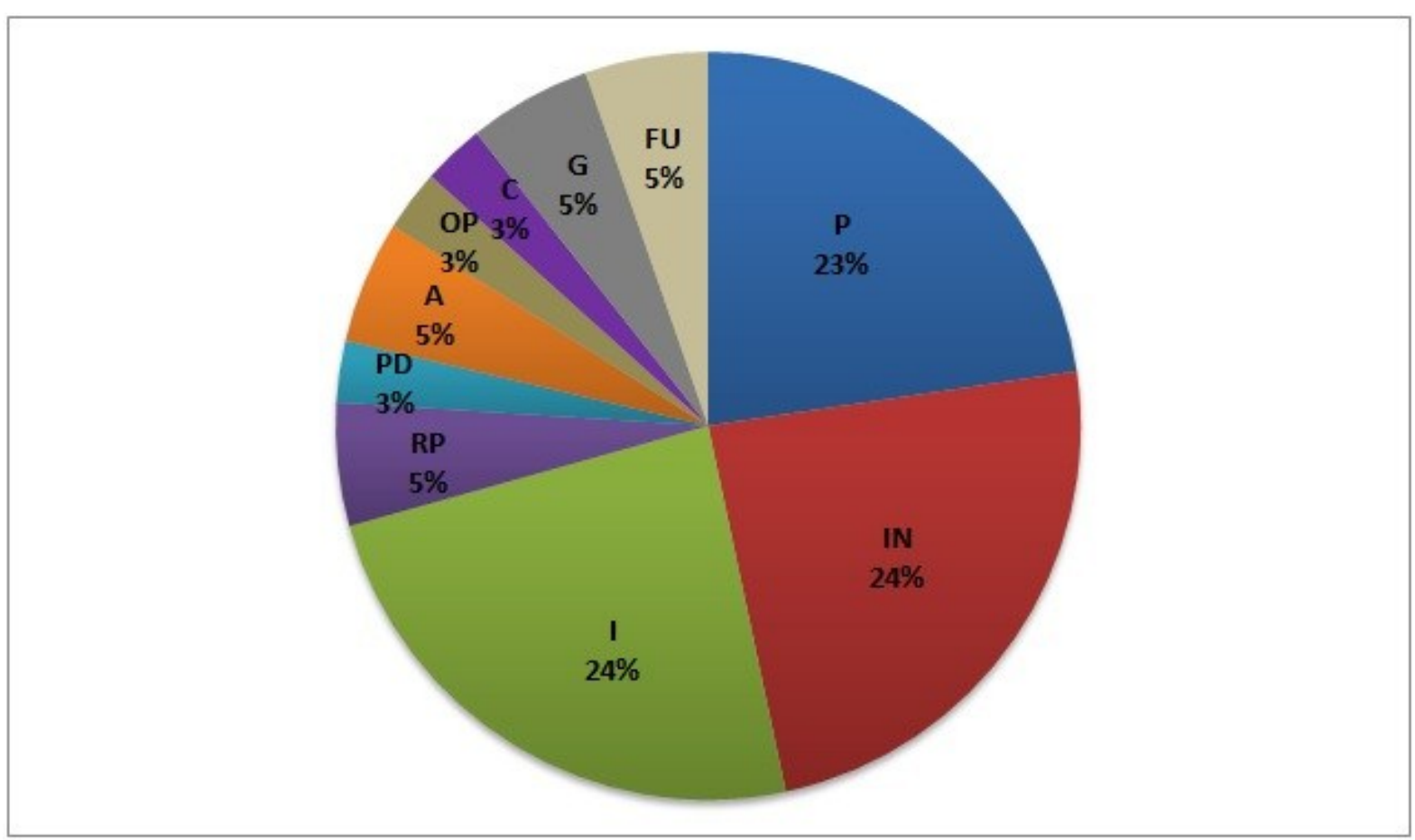

Figure 3: Pie Chart showing the number of bird species observed according to their Feeding Guilds 
In order to visually represent the diversity of the avian community a Dominance-Diversity Curve [17] has been plotted in Figure 4.

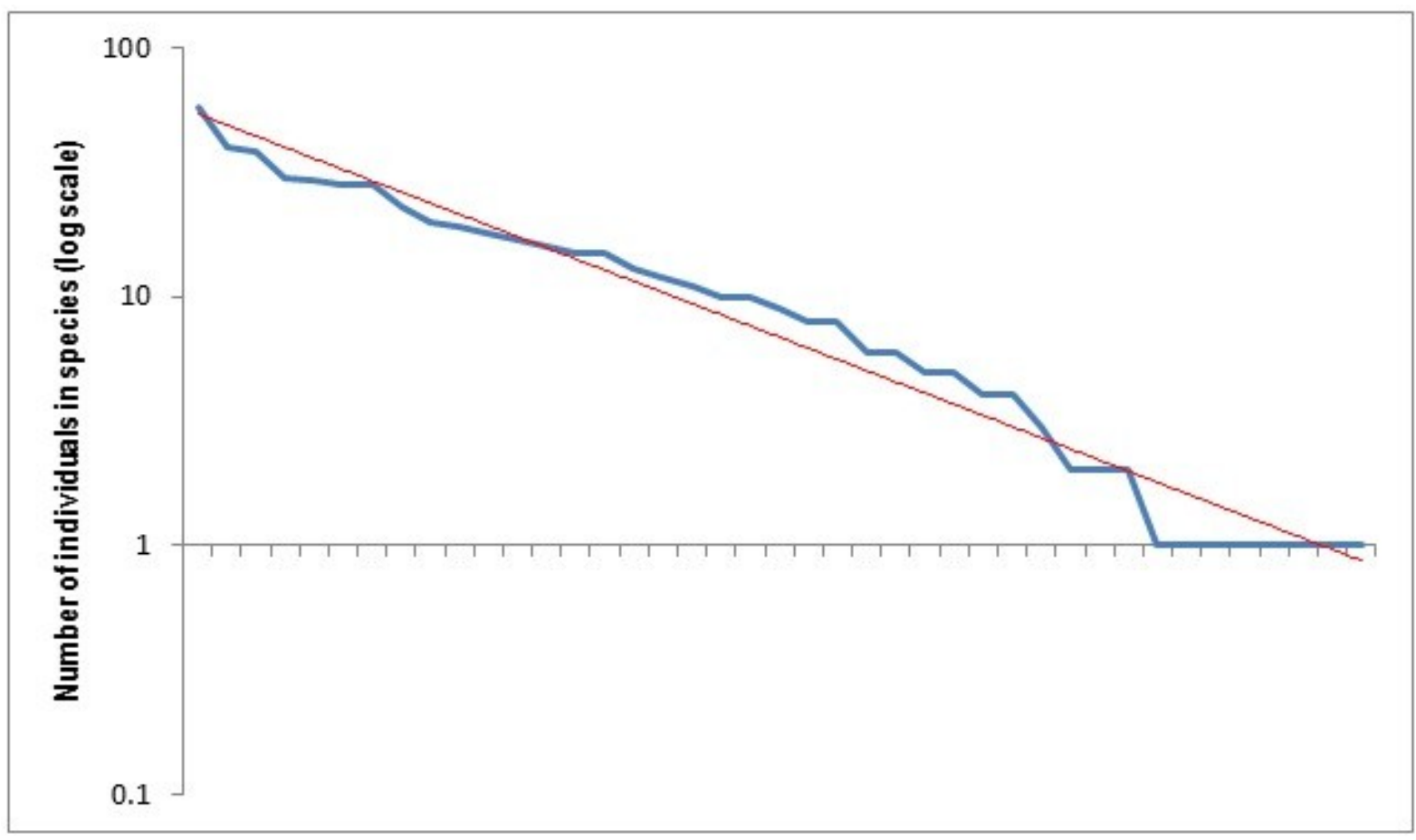

Figure 4: A Dominance-Diversity curve or Species Importance Curve of the bird species

The values of the various diversity indices have been provided in the Table 3 . We have observed that the high values of the Simpson Diversity Index (0.9512) indicate to the high amount of diversity observed in the avian community.

Table 3: Values of the various indices as calculated via PAST are provided under four subcategories; viz. Richness, Diversity, Dominance and Evenness Indices.

\begin{tabular}{|l|l|l|}
\hline $\begin{array}{l}\text { Sr. } \\
\text { No. }\end{array}$ & \multicolumn{1}{|c|}{ NAME OF THE INDICES } & VALUE \\
\hline \multicolumn{4}{|c|}{ Richness Indices } \\
\hline 1. & Family Richness & 21 \\
\hline 2. & Genus Richness & 27 \\
\hline 3. & Species Richness & 35 \\
\hline \multicolumn{5}{|l|}{ Diversity Indices } \\
\hline 1. & Simpson Diversity Index & 0.9512 \\
\hline 2. & Shannon -Wiener Index & 3.238 \\
\hline \multicolumn{5}{|l|}{ Dominance Index } \\
\hline 1. & Simpson's index of dominance & 0.04885 \\
\hline \multicolumn{5}{|l|}{ Evenness Index } \\
\hline 1. & Shannon evenness Index & 0.7283 \\
\hline
\end{tabular}

\section{DISCUSSION}

Wetlands and natural grasslands are important habitats for avian populations throughout the world and the studied one provides no exception. The overall condition of the wetland is pretty good and show signs of a self-sustainable environment; which is mostly because of the very sparse human interventions. This enabled us to study the wetland at its ecological prime. 
The dominance-diversity curve (in the Figure 4) has been plotted in order to get an idea of the amount of diversity observed in the studied avian community. In this case, the trend-line on the curve shows that the studied community exhibits a high amount of diversity; because of the petite angle of intersection and the right-hand side alignment of the curve.

The calculated values of the various diversity indices, especially that of the Simpson Dominance (1) $=0.04885$ proves that the community of avifaunal species show very low amount of dominance. This in the other hand depicts the considerably high diversity of the avian community. The maximum value of the Simpson Diversity Index $\left(D_{S}\right)$ can be 1 [22]. Here, its value is 0.9512 . The value of the Shannon-Wiener Diversity Index $\left(\mathrm{H}^{\prime}\right)$ of the studied community depicts that the chances for getting an individual of the same species in a random sample is about 3.24; which points out to the considerably vast population size of almost every species sampled during our study. When converted to ENS, its value becomes approximately 25.48; which means that a community with Shannon index of 3.24 has an equivalent diversity as a community with almost 26 equally-abundant species. This is further proved by the fact that the value of Shannon Evenness Index ( $\mathrm{J}$ '); which being quite close to 1 shows that there is a moderate amount of variance in the population size of different avian species. Species diversity being more positively correlated with evenness [23]; testifies to the sizeable diversity observed in the studied avian community. The overall scenario as evident via the calculated values of these diversity indices (Table 3 ) is that, the sampled community is greatly diverse in its composition.

The pie-chart depicting the Feeding Guilds of the various avifauna (Figure 3) observed, clearly shows that the community of this particular ecosystem is also sufficiently rich and greatly diversified and hence able to support birds with such a varied spectrum of feeding-habits.

\section{CONCLUSION}

On the basis of our study, we can now conclude that the avian community observed at the coastland shows very little dominance, but a fairly high amount of diversity. In addition, the presence of the various feeding guilds bear proof to the fact that the entire ecological community is fairly diverse and show signs of a healthy environment, despite clear anthropogenic interventions.

\section{Acknowledgements}

We are deeply indebted to Forest Department, Government of Gujarat for permitting us to carry out our work. We also express our heartiest gratitude to the accompanying students of the Zoology Department, Vijaygarh Jyotish Ray College for their help during the study.

\section{References}

[1] S. Buckton, Managing wetlands for sustainable livelihoods at KoshiTappu, Danphe 16(1): 1213, (2007).

[2] R. H. Whittaker and G. E. Likens, Primary production: the biosphere and man, Human Ecology, 1: 357-369, (1973).

[3] J.P. Gibbs, The importance of small wetlands for the persistence of local populations of wetland-associated animals, Wetlands, 13: 25-31, (1993).

[4] M. Paracuellos, How can habitat selection affect the use of a wetland complex by waterbirds?, Biodiversity and Conservation, 15: 4569-4582, (2006).

[5] S. Ali and S. D. Ripley, Handbook of the Birds of India and Pakistan (Compact Edition), University Press, Bombay, India, (1983).

[6] M. M. Weller, Freshwater marshes and wildlife management, University of Minnesota Press. Minneapolis, (1981). 
[7] I. Newton, The contribution of some recent research on birds to ecological understanding, Journal of Animal Ecology, 64: 675-696, (1995).

[8] Sekercioglu and C. Hakki, Ecological significance of bird populations, Handbook of the Birds of the World, 11: 15-51, (2006).

[9] S.A.J. Van, Biodiversity declining in the Netherlands: an indicator to describe the changes in the number of wild species, Netherlands Official Statistics, Winter, 45-49 pp., (1997).

[10] Information on http://www.jamnagar.org/mnp.htm

[11] SACON ENVIS Newsletter on wetland ecosystems and inland wetland; Sarovar Saurabh, Govt. of India. 8(4): 1-5, (2012).

[12] N.B. Gajera, A.K.R. Mahato and V.V. Kumar, Wetland birds of arid region-a study on their diversity and distribution pattern in kachchh, Columban Jornal of Life Science, 13(1 \& 2): 47-51, (2012).

[13] O.D. Stanley, Wetland ecosystems and coastal habitat diversity in Gujarat, India, Journal of Coastal Development, 7(2): 49-64, (2004).

[14] D. W. Gibbons and R. D. Gregory, Birds, in Ecological Census Techniques: a handbook, 2nd (W.J. Sutherland) Edition. Cambridge University Press, Cambridge, 308-350 pp., (2006).

[15] R. Grimmett, C. Inskipp and T. Inskipp, Birds of the Indian Subcontinent, Oxford University Press, New Delhi, (2011).

[16] R. Manakadan and A. Pittie, Standardized common and scientific names of the birds of the Indian subcontinent, Buceros 6(1): 1-37, (2001).

[17] J. E. Bower, J. H. Zar and C. N. von Ende, Field and Laboratory Manual of General Ecology, WCB Mc. Graw -Hill, Boston, 171-193 pp., (1997).

[18] Ø. Hammer, D.A.T. Harper and P. D. Ryan, PAST: Paleontological Statistics Software Package for Education and Data Analysis, Palaeontologia Electronica, 4(1): 9, (2001).

[19] L. Jost, Entropy and diversity, Oikos, 113: 363-375, (2006).

[20] IUCN IUCN Red List Categories and Criteria: Version 3.1, IUCN Species Survival Commission, IUCN, Gland, Switzerland and Cambridge, UK, (2001).

[21] S. Ali and S.D. Ripley, Compact handbook of the birds of India and Pakistan together with those of Bangladesh, Nepal, Bhutan and Sri Lanka, Oxford University Press, Delhi, (1987).

[22] A.E. Magurran, Measuring Biological Diversity, Blackwell, (2004).

[23] C.E. Bock, Z.F. Jones and J.H. Bock, Relationships between species richness, evenness, and abundance in a southwestern savanna, Ecology, 88(5): 1322-1327, (2007). 